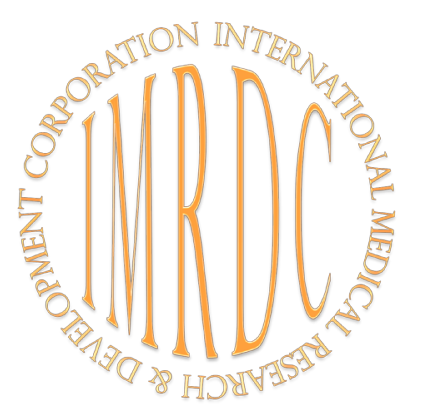

\title{
Adipocytokine Imbalance and Ghrelin in the Development of Insulin Resistance in Patients with Chronic Hepatitis C
}

\author{
Larisa Tkachenko, $\mathrm{PhD}^{* 1}$; Viktor Maleev, $\mathrm{PhD}, \mathrm{ScD}^{2}$; Ludmila Rtishcheva, $\mathrm{PhD}, \mathrm{ScD}^{1}$

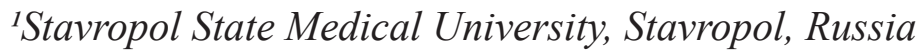 \\ ${ }^{2}$ Central Research Institute of Epidemiology, the Federal Service for Surveillance \\ on Consumer Rights Protection and Human Wellbeing, Moscow, Russia
}

\begin{abstract}
The aim of this study was to determine the role of the most informative indicators of adipocytokine status and ghrelin in insulin resistance (IR) formation in chronic hepatitis C (CHC) patients at different stages of liver fibrosis.

Materials and Methods: This study included 205 CHC patients with HCV genotypes 1 and 3. A comparative analysis of the laboratory parameters was carried out in a group of patients with IR $(n=110)$ and without $I R(n=95)$ and in patients depending on the stage of liver fibrosis. The serum levels of adipocytokines and ghrelin were determined using Bachem Group (USA) and Immundiagnostik AG (Germany) test systems with microplate reader Elx800 (FinBio, Finland). Diagnosis and assessment of the degree of fibrosis was performed by liver biopsy, liver elastometry and calculation test FibroTest.

Results: Obtained data allow us to regard the decreased secretion of ghrelin, and increased production of leptin, resistin and TNF- $\alpha$ as a component involved in the formation of IR in CHC patients. (Int $\mathbf{J}$ Biomed. 2016;6(1):27-32.).

Keywords: chronic hepatitis C; adipocytokines; ghrelin; insulin resistance.

\section{Introduction}

Hepatitis C virus (HCV) infection affects hundreds of millions of people worldwide. Globally, the prevalence and number of people with anti-HCV has increased from $2.3 \%$ to $2.8 \%$ and from $>122$ million to $>185$ million between 1990 and 2005 [1].

Most acutely infected patients develop chronic hepatitis and become a potential source of virus transmission, and as many as 1 in 5 will develop cirrhosis and its complications [2]. HCV is also an increasingly recognized important cause of extrahepatic manifestations, including insulin resistance (IR) [3]. IR is of global importance since it is closely linked to the epidemic condition of obesity, precedes and predicts the development of type 2 diabetes mellitus (T2DM), and increases the risk of life-threatening complications such as cardiovascular diseases, renal failure, and infections [4]. However, these complications are not major causes of death in cirrhotic patients with IR. In contrast, the development of intrahepatic complications, including hepatocellular

*Corresponding author: Larisa Tkachenko, PhD. The Stavropol State Medical University,. Stavropol, Russia. E-mail: larisa308@mail.ru

carcinoma (HCC), is known to be associated with IR [5]. IR is extremely common in patients with chronic $\mathrm{HCV}$ infection and has been associated with increased disease severity, extrahepatic manifestations and decreased response to antiviral therapy $[6,7]$. Whereas the overall prevalence of IR is $10 \%-25 \%$ of the population [8], the prevalence IR in HCV infection reaches figures ranging from $30 \%$ to $70 \%[9,10]$. Moreover, IR with HCV infection is increased at early stages of liver disease without liver fibrosis (LF), and is on average significantly higher than that found in patients with chronic hepatitis B, matched for age and body mass index (BMI) [11]. Understanding the basis of such associations is of paramount importance to inform treatment strategies for patients with $\mathrm{HCV}$.

The main acquired factors of IR include abdominal obesity, aging, hyperglycemia, medications, and, recently, $\mathrm{HCV}$ infection. Obesity is associated with IR, hepatic steatosis and over-expression of TNF- $\alpha$. All of these factors increase the risk of fibrosis and decreased antiviral efficacy. With obesity, the increased adipocytes produce both free fatty acids (FFAs), and adipocytokines. Adipocytokines, including leptin, resistin, TNF- $\alpha$, and IL-6 cause liver injury associated with fat infiltration, causing steatosis, inflammation and LF. All these substances affect tissue sensitivity to insulin:
\end{abstract}


activation of TNF- $\alpha$ causes IR, the elevated level of leptin, which is also able to reduce the action of insulin in the liver, which was detected with obesity. Both TNF- $\alpha$, and leptin have autocrine antilipolytic effect and inhibit the action of insulin in adipocytes themselves [12]. There are data that attest to the role of ghrelin, a peptide hormone produced by ghrelinergic cells, in the formation of IR. More than $80 \%$ of circulating ghrelin is synthesized and secreted into the blood by endocrine cells of the gastrointestinal tract [13]. It was found that ghrelin decreases the utilization of fat, promotes obesity (stimulates lipogenesis and inhibits lipolysis), and activates the synthesis of lipids by the liver. Ghrelin hypersecretion causes obesity. However, with the development of obesity, the ghrelin level in the blood decreases and persistent hypoghrelinemia occurs [14]. We have determined an inverse relationship between ghrelinemia and IR in adults and children: the lower the level, the more pronounced the IR [15]. In HCV infection, adipocytokines and ghrelin may be a link between viral infection, steatosis and metabolic disorders [16].

The aim of this study was to determine the role of the most informative indicators of adipocytokine status and ghrelin in IR formation in chronic hepatitis $\mathrm{C}(\mathrm{CHC})$ patients at different stages of LF.

\section{Materials and Methods}

We examined 205 CHC patients (mean age 44.2 \pm 10.3 ) with HCV genotypes 1 and 3. Males (128/62.4\%) and the patients with HCV genotype $1(123 / 60.0 \%)$ dominated. A comparative analysis of the laboratory parameters was carried out in a group of patients with IR $(n=110)$ and without IR $(\mathrm{n}=95)$ and in patients depending on the stage of LF.

The study was conducted in accordance with ethical principles of the Declaration of Helsinki and approved by the Stavropol State Medical University Ethics Committee. Written informed consent was obtained from all participants.

The observation was conducted during 2011-2014 in the outpatient departments of Stavropol Regional Clinical Consultative and Diagnostic Center.

The examination was conducted in accordance with EASL Clinical Practice Guidelines [17]. HCV infection was defined by the presence in serum of anti-HCV antibodies using the third generation ELISA. HCVs infection was confirmed by performing the COBAS TaqMan HCV-test. The RNA titter was expressed in international units $(\mathrm{IU} / \mathrm{mL})$. The detection limit is $<40 \mathrm{IU} / \mathrm{mL}$ with a positive rate of $95 \%$.

The serum concentrations of total cholesterol (TC), triglycerides (TG), low-density lipoprotein cholesterol (LDL-C), very low-density lipoprotein (VLDL-C), and highdensity lipoprotein cholesterol (HDL-C) were evaluated using test systems of the company Thermo Fisher Sientific (Finland) with the automatic biochemical analyzer Konelab 30i (Finland).

The serum concentration of insulin $(\mu \mathrm{IU} / \mathrm{ml})$ was determined using the Human Insulin ELISA kit from DRG Diagnostics (Germany). For ELISA assays, a microplate reader Elx800 (FinBio, Finland) was used. IR status was calculated by using the homeostatic model assessment-insulin resistance (HOMA-IR); it was determined by the equation: HOMA-IR $=($ fasting insulin $[\mu \mathrm{IU} / \mathrm{mL}] \times$ fasting glucose $[\mathrm{mM} / \mathrm{L}]] / 22.5$. IR was considered as HOMA-IR $>2.77$.

The serum levels of adipocytokines and ghrelin were determined using Bachem Group (USA) and Immundiagnostik AG (Germany) test systems with microplate reader Elx800 (FinBio, Finland).

Diagnosis and assessment of the degree of fibrosis was performed by liver biopsy, liver elastometry and calculation test FibroTest (BioPredictive, France). Knodell Histology Activity Index (HAI) was used to grade necro-inflammatory activity (Knodell et al., 1981). METAVIR group scoring system (F0-F4) was used for detecting the stage of fibrosis (French METAVIR, 1994). Hepatic steatosis was determined by ultrasound examination.

Metabolic syndrome (MetS) was defined according to IDF (2005) criteria [18]. Central (abdominal) obesity was determined as waist circumference (WC) $\geq 94 \mathrm{~cm}$ for men and $\geq 80 \mathrm{~cm}$ for women.

Exclusion criteria were antiviral therapy before liver biopsy, regular consumption of alcohol ( $>30 \mathrm{~g} /$ day ethanol for men and $>20 \mathrm{~g}$ /day ethanol for women), and co-infection with other viruses (HBV, HAV, HDV, HIV), drug-induced and autoimmune hepatitis.

Thirty-five healthy volunteers, matched for sex, age and BMI, served as a control group.

The statistical analysis was performed using the statistical software «Primer of Biostat 4.0» and «STATISTICA 7». The mean (M) and standard deviation (SD) were calculated. For data with normal distribution, inter-group comparisons were performed using Student's t-test. Differences of continuous variables departing from the normal distribution were tested by the Mann-Whitney U-test. Comparisons between three groups were performed with the one-way ANOVA with Tukey's post-hoc test. Spearman's rank correlation coefficient was calculated. Group comparisons with respect to categorical variables are performed using chi-square tests with Yates correction or, alternatively, 2-Tail Fisher's exact test when expected cell counts were less than 5 .

Sensitivity, specificity, positive predictive value, and negative predictive value for each variable were calculated, including 95\% confidence intervals (CIs) and relative risk (RR). A probability value of $P<0.05$ was considered statistically significant.

\section{Results}

HOMA-IR $\geq 2.77$ was detected in $110 / 53.7 \%$ patients, hepatic steatosis in $61 / 29.8 \%$ patients, T2DM in $40 / 19.5 \%$ patients, and severe LF (METAVIR stage, F3 or F4) in $87 / 42.4 \%$ patients, including liver cirrhosis in $54 / 62.1 \%$ patients.

It was found that $\mathrm{CHC}$ patients with IR were older, they had a longer duration of disease, higher BMI and symptoms of abdominal obesity, compared to the patients with HOMA$\mathrm{IR}<2.77$ (Table 1). Moreover, in the IR group, there were more patients who were overweight and obese compared to $\mathrm{CHC}$ patients without IR, $89.0 \%$ and $40 \%(P<0.001)$, respectively. 
In the HOMA-IR $\geq 2.77$ group, cholestatic syndrome was formed, evidenced by the significantly higher rate of total and conjugated bilirubin and alkaline phosphatase. This group of patients was characterized by a higher HAI and METAVIR F stage, with no difference in viral load.

Table 1.

Baseline characteristics for studied patients

\begin{tabular}{|l|c|c|c|}
\hline \multicolumn{1}{|c|}{ Variable } & $\begin{array}{c}\text { HOMA-IR } \\
\geq 2.77 \\
\mathrm{n}=110\end{array}$ & $\begin{array}{c}\text { HOMA-IR } \\
<2.77 \\
\mathrm{n}=95\end{array}$ & P-value \\
\hline HCV Genotype 1, $\mathrm{n} / \%$ & $75 / 68.2$ & $48 / 50.5$ & 0.01 \\
\hline Steatosis, $\mathrm{n} / \%$ & $51 / 46.4$ & $10 / 10.5$ & 0.000 \\
\hline Age, yrs & $46.0 \pm 8.5$ & $40.8 \pm 11.1$ & 0.000 \\
\hline Duration of the disease, yrs & $13.3 \pm 7.8$ & $10.2 \pm 6.6$ & 0.003 \\
\hline Body mass index, kg/m ${ }^{2}$ & $28.8 \pm 5.2$ & $25.6 \pm 4.6$ & 0.000 \\
\hline Waist, cm & $94.1 \pm 18.5$ & $82.0 \pm 14.3$ & 0.000 \\
\hline WHR & $0.92 \pm 0.14$ & $0.8 \pm 0.1$ & 0.000 \\
\hline Total bilirubin, $\mu \mathrm{mol} / 1$ & $22.9 \pm 16.4$ & $16.4 \pm 8.2$ & 0.001 \\
\hline Conjugated bilirubin, $\mu \mathrm{mol} / 1$ & $7.7 \pm 5.5$ & $4.9 \pm 2.6$ & 0.000 \\
\hline ALT/N & $3.1 \pm 2.6$ & $2.5 \pm 2.0$ & 0.069 \\
\hline AST/N & $2.4 \pm 1.9$ & $1.6 \pm 1.2$ & 0.000 \\
\hline$\gamma$-glutamyl transferase/N & $1.9 \pm 1.6$ & $1.9 \pm 2.1$ & 1.000 \\
\hline Alkaline phosphatase/N & $1.3 \pm 0.9$ & $1.0 \pm 0.7$ & 0.009 \\
\hline Fasting glucose, $\mathrm{mmol} / 1$ & $6.0 \pm 1.3$ & $4.9 \pm 1.4$ & 0.000 \\
\hline Fasting insulin, $\mu \mathrm{IU} / \mathrm{ml}$ & $19.2 \pm 9.7$ & $6.8 \pm 3.4$ & 0.000 \\
\hline HOMA-IR & $5.1 \pm 2.7$ & $1.5 \pm 0.7$ & 0.000 \\
\hline Knodell HAI & $11.2 \pm 2.6$ & $8.9 \pm 3.0$ & 0.000 \\
\hline METAVIR F0-F4 & $2.8 \pm 1.0$ & $1.9 \pm 1.2$ & 0.000 \\
\hline Viral load, log $10 \mathrm{IU} / \mathrm{ml}$ & $5.2 \pm 1.3$ & $5.2 \pm 1.4$ & 1.000 \\
\hline
\end{tabular}

TC level was higher in both groups compared with the control, but within the reference values $(5.2 \mathrm{mmol} / \mathrm{l})$. The decrease of HDL-D accompanied by increased VLDL-C in patients with IR contributed to the formation of secondary dyslipidemia of IV type by D. Fredrickson,1970 (Table 2).

Table 2.

\section{Laboratory data of studied groups in relation to IR}

\begin{tabular}{|l|c|c|c|c|c|}
\hline \multicolumn{1}{|c|}{ Variable } & $\begin{array}{c}\text { Control } \\
\text { group } \\
\mathrm{n}=35\end{array}$ & $\begin{array}{c}\text { HOMA-IR } \\
\geq 2.77 \\
\mathrm{n}=110(\mathrm{a})\end{array}$ & $P_{a-b}$ & $\begin{array}{c}\text { HOMA-IR } \\
<2.77 \\
\mathrm{n}=95(\mathrm{~b})\end{array}$ & $\begin{array}{c}\text { one- } \\
\text { way } \\
\text { ANOVA } \\
P \text {-value }\end{array}$ \\
\hline TC, $\mathrm{mmol} / \mathrm{l}$ & $4.14 \pm 0.6$ & $4.9 \pm 1.5^{*}$ & 0.509 & $4.7 \pm 1.2$ & 0.011 \\
\hline $\mathrm{TG}, \mathrm{mmol} / \mathrm{l}$ & $1.36 \pm 0.34$ & $1.4 \pm 0.6$ & 0.000 & $1.1 \pm 0.5^{*}$ & 0.000 \\
\hline HDL-C, $\mathrm{mmol} / 1$ & $1.3 \pm 0.32$ & $0.9 \pm 0.3^{*}$ & 0.000 & $1.2 \pm 0.4$ & 0.000 \\
\hline LDL-C, $\mathrm{mmol} / 1$ & $1.7 \pm 0.66$ & $3.3 \pm 1.3^{*}$ & 0.383 & $3.1 \pm 0.9^{*}$ & 0.000 \\
\hline VLDL-C, $\mathrm{mmol} / 1$ & $0.49 \pm 0.14$ & $0.6 \pm 0.3$ & 0.011 & $0.5 \pm 0.2$ & 0.006 \\
\hline Resistin, $\mathrm{ng} / \mathrm{ml}$ & $8.2 \pm 1.4$ & $15.7 \pm 9.1^{*}$ & 0.000 & $10.4 \pm 5.9^{*}$ & 0.000 \\
\hline Leptin, $\mathrm{ng} / \mathrm{ml}$ & $5.8 \pm 1.1$ & $23.0 \pm 16.2^{*}$ & 0.000 & $13.6 \pm 14.0^{*}$ & 0.000 \\
\hline Adiponectin, $\mu \mathrm{g} / \mathrm{ml}$ & $11.5 \pm 1.3$ & $20.9 \pm 18.5^{*}$ & 0.760 & $22.4 \pm 13.5^{*}$ & 0.001 \\
\hline Ghrelin, $\mathrm{ng} / \mathrm{ml}$ & $0.4 \pm 0.1$ & $0.3 \pm 0.2$ & 0.000 & $0.8 \pm 0.5^{*}$ & 0.000 \\
\hline TNF- $\alpha, \mathrm{pg} / \mathrm{ml}$ & $0.6 \pm 0.2$ & $4.3 \pm 4.8^{*}$ & 0.001 & $2.4 \pm 2.6^{*}$ & 0.000 \\
\hline
\end{tabular}

$*_{-} P<0.05$ in comparison with control group

In the HOMA-IR $\geq 2.77$ group, a significant increase in indices both of pro-inflammatory adipocytokines (resistin,
TNF- $\alpha$, leptin) and of anti-inflammatory hormone adiponectin was revealed on the background of ghrelin decrease.

With the progression of fibrosis, the number of patients with IR has increased. IR was detected in $23.5 \%$ of patients with METAVIR F0-1 stage, in $56.7 \%$ of patients with METAVIR F2 stage, in $68.7 \%$ of patients with METAVIR F3 stage, and in $68.5 \%$ of patients with METAVIR F4 stage $(P<0.001)$.

CHC patients with early signs of fibrosis (F01 METAVIR) and IR+ compared to IR- (Table 3) was characterized by metabolic changes and increased TNF- $\alpha$ blood level. Ghrelin level, in contrast, was lower on the background of IR. In the group of patients with IR, we found a high negative correlation of ghrelin with resistin $(\mathrm{rs}=-0.77)$, leptin ( $\mathrm{rs}=-0.87)$, BMI ( $\mathrm{rs}=-0.9)$, WC ( $\mathrm{rs}=-0.77)$, waist-hip ratio (WHR) $(\mathrm{rs}=-0.67)$, and HOMA-IR $(\mathrm{r}=-0.79)(\mathrm{P}<0.001$ for each value). In patients with METAVIR F0-1 stage, IR was associated with a decrease in ghrelin level (Table 4).

Table 3.

Laboratory data of studied patients with METAVIR F0-1 in relation to IR

\begin{tabular}{|l|c|c|c|}
\hline \multicolumn{1}{|c|}{ Variable } & $\begin{array}{c}\mathrm{IR}(+) \\
\mathrm{n}=12\end{array}$ & $\begin{array}{c}\mathrm{IR}(-) \\
\mathrm{n}=39\end{array}$ & $\begin{array}{c}\text { MW U-test } \\
P \text {-value }\end{array}$ \\
\hline BMI, $\mathrm{kg} / \mathrm{m}^{2}$ & $26.7 \pm 3.6$ & $24.8 \pm 3.2$ & $>0.05$ \\
\hline Waist, $\mathrm{cm}$ & $89.5 \pm 12.2$ & $79.5 \pm 12.3$ & 0.007 \\
\hline WHR & $0.88 \pm 0.1$ & $0.79 \pm 0.1$ & 0.01 \\
\hline Total bilirubin, $\mu \mathrm{mol} / \mathrm{l}$ & $21.9 \pm 6.9$ & $16.2 \pm 6.5$ & 0.006 \\
\hline Conjugated bilirubin, $\mu \mathrm{mol} / 1$ & $4.4 \pm 1.4$ & $5.0 \pm 1.7$ & $>0.05$ \\
\hline Triglycerides, $\mathrm{mmol} / 1$ & $1.2 \pm 0.4$ & $0.9 \pm 0.4$ & 0.01 \\
\hline HDL-C, $\mathrm{mmol} / 1$ & $1.1 \pm 0.1$ & $1.2 \pm 0.2$ & 0.05 \\
\hline LDL-C, $\mathrm{mmol} / 1$ & $2.8 \pm 1.1$ & $3.2 \pm 0.7$ & $>0.05$ \\
\hline VLDL-C, $\mathrm{mmol} / \mathrm{l}$ & $0.6 \pm 0.2$ & $0.4 \pm 0.2$ & 0.01 \\
\hline Fasting glucose, $\mathrm{mmol} / 1$ & $5.9 \pm 1.3$ & $5.2 \pm 2.3$ & $>0.05$ \\
\hline Fasting insulin, $\mu \mathrm{IU} / \mathrm{ml}$ & $15.4 \pm 2.8$ & $7.4 \pm 3.3$ & 0.001 \\
\hline Viral load, log $\mathrm{IU} / \mathrm{ml}$ & $5.4 \pm 0.9$ & $5.5 \pm 1.4$ & $>0.05$ \\
\hline Resistin, $\mathrm{ng} / \mathrm{ml}$ & $14.4 \pm 8.3$ & $12.3 \pm 5.1$ & $>0.05$ \\
\hline Leptin, $\mathrm{ng} / \mathrm{ml}$ & $20.9 \pm 15.8$ & $13.3 \pm 12.3$ & $>0.05$ \\
\hline Adiponectin, $\mu \mathrm{g} / \mathrm{ml}$ & $22.4 \pm 14.0$ & $27.9 \pm 15, .0$ & $>0.05$ \\
\hline Ghrelin, $\mathrm{ng} / \mathrm{ml}$ & $0.3 \pm 0.3$ & $0.6 \pm 0.3$ & 0.001 \\
\hline TNF- $\alpha, \mathrm{pg} / \mathrm{ml}$ & $2.4 \pm 0.5$ & $1.8 \pm 0,8$ & 0.004 \\
\hline
\end{tabular}

Table 4.

Laboratory data in an association with IR in CHC patients with METAVIR F0-1

\begin{tabular}{|l|c|c|c|c|}
\hline \multirow{2}{*}{ Variable } & \multicolumn{2}{|c|}{ F 0-1 $(\mathrm{n}=51)$} & Yates' $\chi 2$ & \multirow{2}{*}{$P$} \\
\cline { 2 - 4 } & $\mathrm{IR}+(\mathrm{n}=12)$ & $\mathrm{IR}-(\mathrm{n}=39)$ & & \\
\hline TC $>5.2 \mathrm{mmol} / 1$ & $5 / 41.7$ & $11 / 28.2$ & 0.274 & 0.6007 \\
\hline $\mathrm{TG}>1.7 \mathrm{mmol} / 1$ & $3 / 25$ & $3 / 7.7$ & FET & 0.13377 \\
\hline HDL-C $<1 \mathrm{mmol} / 1$ & $1 / 8.3$ & $5 / 12.8$ & FET & 1.0000 \\
\hline Fasting glucose $>6 \mathrm{mmol} / 1$ & $4 / 33.3$ & $3 / 7.7$ & FET & 0.0445 \\
\hline Ghrelin $<0.4 \mathrm{ng} / \mathrm{ml}$ & $8 / 66.6$ & $10 / 25.6$ & 5.086 & 0.0241 \\
\hline Resistin $>8.2 \mathrm{ng} / \mathrm{ml}$ & $8 / 66.6$ & $22 / 56.4$ & 0.088 & 0.7667 \\
\hline Leptin $>5.8 \mathrm{ng} / \mathrm{ml}$ & $10 / 83.3$ & $27 / 69.2$ & 0.345 & 0.5569 \\
\hline Adiponectin $<11.5 \mu \mathrm{g} / \mathrm{ml}$ & $3 / 25$ & $7 / 17.9$ & FET & 0.6822 \\
\hline
\end{tabular}

Results are expressed as absolute numbers and percentages (n/\%), FET - Fisher's Exact Test 
The most significant marker of IR was a reduction in secretion of ghrelin lower than the norm. The test had a high degree of accuracy, specificity, positive and negative predictive value (Table 5). The high negative predictive value and accuracy of the tests showed an increased level of triglycerides $>1.7 \mathrm{mmol} / \mathrm{l}$, a decreased level of HDL-C $<$ $1 \mathrm{mmol} / \mathrm{L}$, and elevated glucose $>6.1 \mathrm{mmol} / \mathrm{L}$.

Table 5.

Diagnostic Significance of IR markers in CHC patients $(n=51)$ with METAVIR F0-1

\begin{tabular}{|l|c|c|c|c|c|c|c|}
\hline \multicolumn{1}{|c|}{ Variable } & PPV\% & NPV\% & Ac\% & RR & $95 \%$ CI & Se\% & Sp\% \\
\hline TC $>5.2 ~ \mathrm{mmol} / 1$ & 41.7 & 71.8 & 64.7 & 1.6 & $1.1-2.4$ & 60.0 & 57.4 \\
\hline TG $>1.7 \mathrm{mmol} / 1$ & 25.0 & 92.3 & 76.5 & 3.1 & $1.5-6.6$ & 75.8 & 55.1 \\
\hline Glucose $>6.1 \mathrm{mmol} / 1$ & 33.3 & 92.3 & 78.4 & 4.1 & $2.0-8.5$ & 80.5 & 57.9 \\
\hline Ghrelin $<0.4 \mathrm{ng} / \mathrm{ml}$ & 66.6 & 74.4 & 72.5 & 2.6 & $1.8-3.7$ & 72.0 & 69.2 \\
\hline Resistin $>8.2 \mathrm{ng} / \mathrm{ml}$ & 66.6 & 43.6 & 49.0 & 1.2 & $1.0-1.5$ & 54.5 & 57.1 \\
\hline Leptin $>5.8 \mathrm{ng} / \mathrm{ml}$ & 83.3 & 30.8 & 43.1 & 1.2 & $1.0-1.4$ & 54.6 & 64.6 \\
\hline
\end{tabular}

Se - sensitive, Sp - specificity, Ac- accuracy; PPV - positive predictive value, $N P V$ - negative predictive value; $R R$ - relative risk

With an increase in the fibrosis stage on the background of IR, relative risk of disorders in lipid and carbohydrate metabolism increased, as well as the development of adipokine imbalance. Thus, in patients with METAVIR F0-1 stage on the background of IR, RR of hypertriglyceridemia increased by 3 times, hyperglycemia by 4 times, and hypoghrelinemia by 2.6 times. The most significant impairments were observed at METAVIR F3 and F4 stages (Table 6).

Table 6.

The risk of metabolic abnormalities and imbalance adipokines in CHC patients with IR according to METAVIR stage

\begin{tabular}{|c|c|c|c|c|c|c|c|c|}
\hline \multirow{3}{*}{ Variable } & \multicolumn{8}{|c|}{ METAVIR F0-F4 } \\
\hline & \multicolumn{2}{|c|}{ F0-1 } & \multicolumn{2}{|c|}{$\mathrm{F} 2$} & \multicolumn{2}{|c|}{ F3 } & \multicolumn{2}{|r|}{$\mathrm{F} 4$} \\
\hline & $\mathrm{RR}$ & \begin{tabular}{|c|}
$95 \%$ \\
CI
\end{tabular} & $\mathrm{RR}$ & $\begin{array}{r}95 \% \\
\text { CI }\end{array}$ & $\mathrm{RR}$ & \begin{tabular}{|c|}
$95 \%$ \\
CI
\end{tabular} & $\mathrm{RR}$ & $\begin{array}{c}95 \% \\
\mathrm{CI}\end{array}$ \\
\hline $\mathrm{TC}>5.2 \mathrm{mmol} / 1$ & 1.6 & $1.1-2.4$ & 1.0 & $0.1-0.8$ & 0.9 & $.7-1$. & & $.0-2$ \\
\hline $\mathrm{TG}>1.7 \mathrm{mmol} / 1$ & $3.1 *$ & $1.5-6.6$ & 1.4 & $1.0-2.1$ & 1.1 & $0.8-$ & & $.6-8$. \\
\hline $\mathrm{HDL}<1 \mathrm{mmol} / 1$ & 0.6 & $0.3-1.4$ & $2.1 *$ & $1.4-3.3$ & $2.6^{*}$ & $1.7-3$ & $2.0^{*}$ & $1.5-2$ \\
\hline $\mathrm{FG}>6.1 \mathrm{mmol} / 1$ & $4.1 *$ & $2.0-8.5$ & $10.7^{*}$ & $3.4-33.7$ & $5.2^{*}$ & 2.8 & & $1.4-4$ \\
\hline Ghr $<0.4 \mathrm{ng} / \mathrm{ml}$ & $2.6 *$ & $|1.8-3.7|$ & 1.0 & $0.8-1.2$ & $4.2^{*}$ & $2.8-3$ & 4.2 & $2.7-6$ \\
\hline $\operatorname{Res}>8.2 \mathrm{ng} / \mathrm{ml}$ & 1.2 & $1.0-1.5$ & 0.9 & $0.8-1.1$ & $2.3^{*}$ & $1.8-2$. & $3.3 *$ & $2.6-4$. \\
\hline Leptin $>5.8 \mathrm{ng} / \mathrm{m}$ & $1.2 *$ & 1.0-1.4 & $0.8^{*}$ & $0.6-0.9$ & $2.2 *$ & $1.7-2.7$ & $1.7 *$ & $1.4-2$. \\
\hline $\mathrm{AP}<11.5 \mu \mathrm{g} / \mathrm{ml}$ & 1.4 & $0.8-2.4$ & $1.7^{*}$ & $1.0-2.5$ & $1.7^{*}$ & $1.2-2.5$ & 1.3 & $0.8-1.5$ \\
\hline
\end{tabular}

$* P<0.05$ in comparison with IR- patients, AP-adiponectin $F G$-fasting glucose, Res-resistin, Ghr-ghrelin

In multivariate regression analysis, the most significant influence on the IR formation in HCV patients with F0-1 fibrosis was glucose, WHR, ghrelin, and cholesterol (Table 7). In the METAVIR F2 stage, IR significantly depended only on the basic parameters of glucose and insulin In the METAVIR F3 stage, in addition to BMI and WHR, IR significantly depended also on the duration of disease, serum levels of leptin and resistin. In patients with liver cirrhosis, the independent predictors of IR were BMI, triglycerides, C-reactive protein, leptin, and resistin.
Table 7.

Multiple linear regression analysis for factors associated with HOMA-IR in CHC patients with different METAVIR stages

\begin{tabular}{|l|c|c|c|c|}
\hline \multicolumn{1}{|c|}{ Variable } & $\begin{array}{l}\text { Regression } \\
\text { coefficient }\end{array}$ & $\begin{array}{c}\text { SE of } \\
\text { regression } \\
\text { coefficient }\end{array}$ & 95\% CI & P-value \\
\hline \multicolumn{5}{|c|}{ METAVIR F0-1 } \\
\hline Ghrelin & -1.183 & 0.259 & -1.753 to -0.613 & $<0.001$ \\
\hline WC & -0.087 & 0.024 & -0.140 to -0.034 & 0.004 \\
\hline WHR & 6.417 & 2.766 & 0.330 to 12.504 & 0.04 \\
\hline Fasting glucose & 0.585 & 0.112 & 0.337 to 0.832 & $<0.001$ \\
\hline TC & -2.020 & 0.426 & -2.957 to -1.083 & $<0.001$ \\
\hline LDL-C & 1.815 & 0.410 & 0.912 to 2.718 & $<0.001$ \\
\hline \multicolumn{5}{|c|}{ METAVIR F2 } \\
\hline Fasting glucose & 0.566 & 0.047 & 0.473 to 0.659 & $<0.001$ \\
\hline Fasting insulin & 0.257 & 0.005 & 0.247 to 0.266 & $<0.001$ \\
\hline \multicolumn{7}{|c|}{ METAVIR F3 } \\
\hline BMI & 0.842 & 0.146 & 0.523 to 1.160 & $<0.001$ \\
\hline Duration of Dis. & -0.231 & 0.039 & -0.317 to $-0,146$ & $<0.001$ \\
\hline Leptin & -0.297 & 0.045 & -0.396 to -0.198 & 0.04 \\
\hline Resistin & 0.106 & 0.05 & -0.01 to 0.22 & 0.04 \\
\hline WHR & 9.3 & 4.6 & -0.737 to 19.34 & 0.045 \\
\hline \multicolumn{7}{|c|}{ METAVIR F4 } \\
\hline BMI & 0.250 & 0.099 & 0.05 to 0.45 & 0.01 \\
\hline Triglycerides & -2.611 & 0.569 & -1.47 to 3.753 & $<0.001$ \\
\hline Leptin & -0.051 & 0.02 & -0.102 to 0.001 & 0.045 \\
\hline Resistin & 0.067 & 0.029 & 0.01 to 0.125 & 0.02 \\
\hline CRP & 0.449 & 0.109 & 0.229 to 0.670 & 0.0001 \\
\hline
\end{tabular}

\section{Discussion}

The causal relationship between HCV infection and IR development has been demonstrated by the increased prevalence of IR in chronic HCV infection even at early stages of liver disease without LF. Patients with IR were characterized by a higher histological activity and hepatic fibrosis index, which coincides with the data of JM Hui et al. and CO Zein et al. [19,20].

$\mathrm{HCV}$-induced IR may be due to the HCV core protein inducing proteasomal degradation of IRSs 1 and 2 blocking intracellular insulin signaling. The latter is mediated by increased levels of both TNF- $\alpha$ and 3 SOC-3 [4]. A model of mice transgenic for the $\mathrm{HCV}$ core protein demonstrated insulin resistance, glucose intolerance, and elevated intrahepatic TNF- $\alpha$ mRNA; all of which were ameliorated by anti-TNF- $\alpha$ antibodies [21]. Currently, TNF- $\alpha$ is identified as a mediator of insulin resistance, which is induced by HCV $[21,22]$. TNF- $\alpha$ have deleterious effects on both glucose homeostasis and betacell function, and can disrupt insulin signalling pathways in both pancreatic beta cells and liver and adipose tissue [23]. Overflow of FFAs from adipose tissue to systemic circulation impairs insulin-mediated glucose uptake by the muscles resulting in hyperglycemia and peripheral IR. In contrast to the data of A.J. Sanyal [24] and S.A Harrison [10], we did not find an association between IR and viral load level.

IR, through different mechanisms, plays a role in the development of steatosis and its progression to steatohepatitis, 
cirrhosis and even HCC [4,25-27]. The overall prevalence of steatosis in patients with $\mathrm{HCV}$ infection is approximately $55 \%$ ranging from $35 \%$ to $81 \%$ in various studies, which is approximately 2 to 3 fold higher than the prevalence of steatosis in other liver disease [28]. The current evidence suggests that $\mathrm{HCV}$-associated hepatic steatosis is mainly virus-induced in genotype-3a infected patients [25], which seems to be mediated by an impaired VLDL-C secretion, most likely via an impaired activity of the liver microsomal triglyceride transfer protein (MTP) [29]. On the contrary, the host-factors (mainly IR) play a major role in steatosis in non-3 genotypes [25].

Peripheral IR increases adipose tissue lipolysis, leading to increased plasma and hepatic uptake of FFAs. Increased hepatic uptake of FFAs impairs $\beta$-oxidation in mitochondria, together with decreased excretion of VLDL, resulting in TG retention with subsequent development of hepatic steatosis [30].

The adipokine system was activated in our patients with $\mathrm{CHC}$, which is reflected in higher levels of leptin, resistin and TNF- $\alpha$, and more pronounced changes have taken place on the background of IR. A higher value of leptin according to E Tsochatzis can enhance IR, increase the cellular pool of fatty acids, and lead to the formation of liver steatosis [31]. B.Mattioli demonstrated that leptin may enhance the production of proinflammatory cytokines, including TNF- $\alpha$ [32]. In CHC patients with IR, resistin was higher than in the control group and in the group of patients without IR. According to M.Hayt [16], this hormone may be involved in the formation of obesity and IR. The adiponectin level did not depend on the presence of IR, but was higher than in the control group. Our study is consonant with data of V.D. Dixit on the inverse relationship of ghrelinemia and IR: the lower the level of ghrelin, the more pronounced is IR [33].

Thus, our data, as well as results of many authors $[11,34,35]$, suggest that $\mathrm{HCV}$ is capable of producing an increase in IR, even before a minimal degree of hepatic fibrosis is present. Alternatively, several studies have reported that IR can adversely affect the course of chronic hepatitis $C$ leading to enhanced steatosis and liver fibrosis $[5,11,36-38]$ and even increase the risk of hepatocellular carcinoma $[5,39]$. At the same time, the presence of advanced liver disease is an even stronger diabetogenic factor than $\mathrm{HCV}$ infection itself. In other words, diabetes associated with $\mathrm{HCV}$ infection is less of a determinate than the effect of hepatic cirrhosis on glucose metabolism [40].

In conclusion, several mechanisms could explain the role of IR in the development of LF. Hyperinsulinemia per se stimulates the proliferation of stellate cells, thus enhancing the secretion of extracelular matrix. Moreover, both insulin and hyperglucemia are able to stimulate the expression of the connective tissue growth factor, a cytokine involved in the progression of fibrosis in the liver and other tissues [40,41]. Visceral adipose tissue is a causative risk factor for fatty liver and nonalcoholic steatohepatitis. [42,43] Visceral fat accumulation impairs adipocyte function and adipocytokine secretion. Our data demonstrates the potential role of adipocytokines in the development of IR, fatty liver and LF.
The most informative indicator in predicting of IR was the reduced ghrelin secretion. Revealed correlations with BMI, WHR, steatosis, insulin and HOMA-IR allow us to regard the decreased secretion of ghrelin, and increased production of leptin, resistin and TNF- $\alpha$ as a component involved in the formation of IR and MetS in CHC patients.

\section{Competing interests}

The authors declare that they have no competing interests.

\section{References}

1. Mohd Hanafi ah K, Groeger J, Flaxman AD, Wiersma ST. Global epidemiology of hepatitis $C$ virus infection: new estimates of age-specific antibody to $\mathrm{HCV}$ seroprevalence. Hepatology, 2013, 57(4):1333-42.

2. Lavanchy D. The global burden of hepatitis C. Liver Int. $2009 ; 29: 74-81$.

3. Galossi A, Guarisco R, Bellis L, Puoti C. Extrahepatic Manifestations of Chronic HCV Infection. J Gastrointestin Liver Dis March. 2007;16:65-73.

4. El-Zayadi AR1, Anis M Hepatitis C virus induced insulin resistance impairs response to anti viral therapy. World $\mathrm{J}$ Gastroenterol. 2012;18(3):212-24. doi: 10.3748/wjg.v18. i3.212.

5. Machado MV, Cortez-Pinto $\mathrm{H}$. Insulin resistance and steatosis in chronic hepatitis C. Ann Hepatol. 2009;8:S67S75.

6. Alberti A, Vario A, Ferrari A, Pistis R. Review article: chronic hepatitis C--natural history and cofactors. Aliment Pharmacol Ther. 2005;22(Suppl 2):74-78

7. Ioannou GN, Ioannou GN, Bryson CL, Boyko EJ. Prevalence and trends of insulin resistance, impaired fasting glucose, and diabetes. J Diabetes Complications. 2007; 21:363-370

8. Ferrannini E, Natali A, Capaldo B, Lehtovirta M, Jacob S, Yki-Järvinen H. Insulin resistance, hyperinsulinemia, and blood pressure: role of age and obesity. European Group for the Study of Insulin Resistance (EGIR) Hypertension. 1997;30:1144-49. 9. Romero-Gómez M. Insulin resistance and hepatitis C. World J Gastroenterol. 2006;12:7075-80.

10. Harrison SA. Insulin resistance among patients with chronic hepatitis C: etiology and impact on treatment. Clin Gastroenterol Hepatol. 2008;6:864-76.

11. Moucari R, Asselah T, Cazals-Hatem D, Voitot H, Boyer $\mathrm{N}$, Ripault MP, et al. Insulin resistance in chronic hepatitis C: association with genotypes 1 and 4, serum HCV RNA level, and liver fibrosis. Gastroenterology. 2008;134:416-423

12. Jalil S, Mummad RR, Sood GK Chronic HCV infection causes insulin resistance - a meta-analysis (abstr). Gastroenterology. 2007; 132:(Suppl 2):A-784.

13. Kawaguchi T, Sata M. Importance of hepatitis $C$ virusassociated insulin resistance: therapeutic strategies for insulin sensitization. World J Gastroenterol. 2010; 16: 1943-52.

14. Leclercq IA, Morais AS, Schroyen B, Hul NV, Geerts A. Insulin resistance in hepatocytes and sinusoidal liver cells: mechanisms and consequences. J Hepatol. 2007; 47:142-56.

15. Mori K, Yoshimoto A, Takaya K, Hosoda K, Ariyasu H, Yahata K, et al. Kidney produces a novel acylated peptide, ghrelin. FEBS Lett. 2000; 486: 213-6.

16. Marra F, Bertolani C. Adipokines in Liver Diseases. 
Hepatology. 2009; 50 (3):957- 69.

17. EASL Clinical Practice Guidelines: Management of hepatitis C virus infection European Association for the Study of the Liver. J Hepatology. 2014; 60(2):392-420.

18. Alberti KG, Zimmet P, Shaw J; IDF Epidemiology Task Force Consensus Group. The metabolic syndrome--a new worldwide definition. Lancet. 2005; 366(9491):1059-62.

19. Hui J M, Sud A, Farrell GC, Bandara P, Byth K,. Kench J $\mathrm{G}$, et al. Insulin resistance is associated with chronic hepatitis $\mathrm{C}$ and virus infection fibrosis progression Gastroenterology. 2003; 125:1695-704.

20. Zein CO, Levy C, Basu A, Zein NN .Chronic hepatitis $\mathrm{C}$ and type II diabetes mellitus: a prospective cross-sectional study. Am J Gastroenterol. 2005;100:48-55.

21. Knobler H1, Schattner A.TNF-\{alpha\}, chronic hepatitis C and diabetes: a novel triad. QJM. 2005 Jan;98(1):1-6.

22. Knobler H1, Zhornicky T, Sandler A, Haran N, Ashur Y, Schattner A. Tumor necrosis factor-alpha-induced insulin resistance may mediate the hepatitis $\mathrm{C}$ virus-diabetes association. Am J Gastroenterol. 2003; 98(12):2751-6.

23. Greenberg AS1, McDaniel ML.Identifying the links between obesity, insulin resistance and beta-cell function: potential role of adipocyte-derived cytokines in the pathogenesis of type 2 diabetes. Eur J Clin Invest. 2002;32 Suppl 3:24-34.

24. Sanyal AJ, Contos MJ, Sterling RK, Luketic VA, Shiffman M L, Stravitz RT et al. Hyperinsulinemia blocks the inhibition of hepatitis $\mathrm{C}$ virus (HCV) replication by interferon: a potential mechanisms for failure of interferon therapy in subjects with $\mathrm{HCV}$ and nonalcoholic fatty liver disease. Hepatology. 2004; 40:179A

25. Adinolfi LE, Gambardella M, Andreana A, Tripodi MF, UtiliR, Ruggiero G. Steatosis accelerates the progression of liver damage of chronic hepatitis $\mathrm{C}$ patients and correlates with specific HCV genotype and visceral obesity. Hepatology. 2001; 33:1358-64.

26. Shaheen M, Echeverry D, Oblad MG, Montoya MI, Teklehaimanot S, Akhtar AJ: Hepatitis C, metabolic syndrome, and inflammatory markers: results from the Third National Health and Nutrition Examination Survey (NHANES III). Diabetes Res Clin Pract. 2007; 75:320-6.

27. Reaven G.M. Compensatory hyperinsulinemia and the development of the atherogenic lipoprotein profile. The price paid to maintain glucose homeostasis in insulin-resistant individuals. Endocrinol Metab Clin North Am. 2005; 34:49-62. 28. Lonardo A, Adinolfi LE, Loria P, Carulli N, Ruggiero G, Day CP. Steatosis and hepatitis $C$ virus: mechanisms and significance for hepatic and extrahepatic disease. Gastroenterology. 2004;126:586-97.

29. McGuinness PH, Painter D, Davies S, McCaughan GW. Increases in intrahepatic CD68 positive cells, MAC387 positive cells, and proinflammatory cytokines (particularly interleukin 18) in chronic hepatitis C infection. Gut. 2000;46:260-269.

30. Chitturi S, Abeygunasekera S, Farrell GC, Holmes-Walker J, Hui JM, Fung C, Karim R, Lin R, Samarasinghe D, Liddle $\mathrm{C}$, et al. NASH and insulin resistance: Insulin hypersecretion and specific association with the insulin resistance syndrome. Hepatology. 2002;35:373-79.

31. Tsochatzis E, Papatheodoridis GV, Archimandritis AJ. The evolving role of leptin and adiponectin in chronic liver diseases Am. J. Gastroenterol. 2006; 101 (11): 2629-40.

32. Mattioli B, Straface E, Quaranta MG, Giordani L, Viora M. Leptin promotes differentiation and survival of human dendritic cells and licenses them for Th1 priming. J Immunol. 2005; 174:6820-8.

33. Dixit VD, Schaffer EM, Pyle RS, Collins G D, Sakthivel SK, Palaniappan R, et al. Ghrelin inhibits leptin and activationinduced proinflammatory cytokine expression by human monocytes and T-cells. J Clin Inv. 2004; 114:57-66.

34. Knobler H, Schihmanter R, Zifroni A, Fenakel G, Schattner A. Increased risk of type 2 diabetes in noncirrhotic patients with chronic hepatitis $\mathrm{C}$ virus infection Mayo Clin Proc. 2000; 75:355-9.

35. Lecube A, Hernández C, Genescà J, Esteban JI, Jardí R, Simó R. High prevalence of glucose abnormalities in patients with hepatitis $\mathrm{C}$ virus infection: a multivariate analysis considering the liver injury. Diabetes Care. 2004; 27:1171-5. 36. Petit JM, Bour JB, Galland-Jos C, Minello A, Verges $\mathrm{B}$, Guiguet $\mathrm{M}$, et al. Risk factors for diabetes mellitus and early insulin resistance in chronic hepatitis C. J Hepatol. 2001;35: 279-83.

37. Cammà C1, Bruno S, Di Marco V, Di Bona D, Rumi M, Vinci $\mathrm{M}$, et al. Insulin resistance is associated with steatosis in nondiabetic patients with genotype 1 chronic hepatitis $\mathrm{C}$. Hepatology. 2006;43(1):64-71.

38. Castéra L1, Hézode C, Roudot-Thoraval F, Bastie A, Zafrani ES, Pawlotsky JM, et al. Worsening of steatosis is an independent factor of fibrosis progression in untreated patients with chronic hepatitis $\mathrm{C}$ and paired liver biopsies. Gut. 2003;52(2):288-92.

39. Tazawa J, Maeda M, Nakagawa M, Ohbayashi H, Kusano F, Yamane M, et al. Diabetes mellitus may be associated with hepatocarcinogenesis in patients with chronic hepatitis C. Dig Dis Sci. 2002; 47:710 -15.

40. Lecube A1, Hernández $\mathrm{C}$, Genescà J, Simó R. Glucose abnormalities in patients with hepatitis $\mathrm{C}$ virus infection: Epidemiology and pathogenesis. Diabetes Care. 2006;29(5):1140-9.

41. Paradis V1, Perlemuter G, Bonvoust F, Dargere D, Parfait B, Vidaud M, et al.High glucose and hyperinsulinemia stimulate connective tissue growth factor expression: a potential mechanism involved in progression to fibrosis in nonalcoholic steatohepatitis. Hepatology. 2001;34(4 Pt 1):738-44.

42. Schäffler A1, Schölmerich J, Büchler C.Mechanisms of disease: adipocytokines and visceral adipose tissue--emerging role in nonalcoholic fatty liver disease. Nat Clin Pract Gastroenterol Hepatol. 2005; 2(6):273-80.

43. Baranova A1, Jarrar MH, Stepanova M, Johnson A, Rafiq N, Gramlich T, et al. Association of serum adipocytokines with hepatic steatosis and fibrosis in patients with chronic hepatitis C. Digestion. 2011;83(1-2):32-40. 